Papavras-chave: aconselhamento genético, anemia falciforme, campo e risco.

\title{
Não deixando a cor passar em branco: \\ o processo de implementação de cotas para estudantes negros na Universidade de Brasília
}

\section{Ernandes Barboza Belchior}

Curso: Mestrado em Sociologia

Data da defesa da dissertação: 28 de março de 2006

Orientadora: $\operatorname{Prof}^{\mathrm{a}} \mathrm{Dr}^{\mathrm{a}}$ Wivian Weller

\section{Resumo}

A dissertação relata como se desenvolveu o processo de implementação de cotas para estudantes negros na Universidade de Brasília, aprovado em 2003. Para isso, analisou-se, através de entrevistas, a participação daqueles atores sociais que estiveram envolvidos nesse processo. Ao escolher esse tema como objeto de estudo sociológico, buscou-se examinar, não só sob uma perspectiva de inclusão social, mas também sob uma ótica de política social, a construção de reconhecimento e identidade para aqueles considerados afrodescendentes.

Palavras-chave: ação afirmativa, cotas raciais, discriminação racial,discriminação positiva, identidade, preconceito racial, racismo e reconhecimento. 